\title{
Lov og ret i Sønderjylland ca. 1500 til ca. 1750
}

\section{Af Frants Thygesen}

Sønderjylland som brydningsområde mellem dansk og tysk er et langt og spændende udsnit af vort lands historie. Det gælder ikke blot mødet mellem dansk og tysk magt, men også sammenstødet mellem dansk og tysk ret. Fra traktaten i 811 med Karl den Store til 1864 gik grænsen for det danske rige i princippet ved Ejderen; men ved nærmere betragtning af Sønderjyllands retsforhold ser man hele udviklingen fra middelalderen, da området var en almindelig dansk landsdel, der dog tidligt blev et særligt hertugdømme som dansk len, men gennem 500 år nøje forbundet med det tyske Holsten, ned til nyere tid, da skellet ved Kongeåen blev trukket skarpt op - som forspil til den fuldstændige afståelse i 1864. Denne udvikling har præget befolkningen, idet man groft tegnet kan sige, at sønderjyderne i hovedsagen har en dansk oprindelse og natur, men gennem langvarigt tryk sydfra og ovenfra er blevet stærkt påvirket af tysk sprog og kultur. Denne forbindelse eller modsætning mellem nordisk natur og tysk kultur lever i mange slesvigere som enkeltpersoner, og for landsdelen som helhed er det foreløbige resultat, at over halvdelen af den $\mathrm{i}$ dag er tysktalende og under tysk styre.

\section{Sønderjyllands retsstilling før reformationen}

Den nævnte dobbeltstilling afspejles i brugen af de to navne Sønderjylland og Slesvig. Da hertugdømmet blev til, kaldtes hertugen på latin "dux Jutiæ» (Jyllands hertug); det ændredes siden til "dux Slesvicensis", hertug af Slesvig, som det hed $\mathrm{i}$ den danske konges titel lige til Margrethe 2. Navnet Slesvig for landsdelen træffes første gang 1340 i en skrivelse fra den holstenske grev Gert (ham, som jyderne kaldte "den kullede“, men holstenerne mden store (), og det kom af byen Slesvig, som var de holstenske grevers fast holdepunkt i det sydlige Sønderjylland og senere de gottorpske hertugers residensby, mens Flensborg oftest var kongens by. Dengang var dog hertugdømmets stilling som len af Danmark helt klar, og indtil 1459 sad de holstenske grever som hertuger af Slesvig i det danske rigsråd; men efter Ribe-aftalen af 1460 var Sønderjylland i en slags realunion med det tyske grevskab Holsten. Denne aftale var jo indgået på den ene side af det holstenske ridderskab, som nu havde overtaget i Slesvig, og på den anden 
side den tyske grev Christian, som netop var blevet konge over Danmark, Norge og Sverige. Fxlles landsherre for de to provinser var dog stadig kongen af Danmark eller de slægtninge, han delte dem med, og navnlig var Sønderjylland stadig dansktalende bortset fra friserne på vestkysten fra Tønder til Ejderen. Kun det sydøstligste hjørne til nord for Egernførde var for alvor tysktalende; desuden havde tysk sprog fảet overtaget i byerne Husum og Slesvig og tildels i Flensborg.

Ved aftalen 1460 blev den tidligere appelvej fra Sønderjylland til Viborg landsting eller kongens retterting afskåret; den politiske hensigt hermed understreges af, at der fra Holsten stadig kunne appelleres til tyske rigsdomstole. I øvrigt var Ejderen endnu ved middelalderens slutning et $k$ lart skel mellem tysk og dansk ret, bortset fra at Tønder havde fået lybsk stadsret ligesom Rensborg, der halvvejs lå i Holsten, og så Burg på Femern, der oprindelig lå under Fyns stift, men siden hørte til hertugdømmet Slesvig. I Holsten gjaldt tysk ret, hovedsagelig Sachsenspiegel fra ca. 1235, i Østholsten dog endnu delvis vendisk ret. Nord for Ejderen gjaldt som almindelig landslov Valdemar Sejrs Jyske Lov af 1241 ved siden af købstædernes stadsretter eller bylove, der klart fremtrådte som danske, både i Slesvig, Flensborg, Ábenrå, Haderslev samt Egernførde og det noget yngre Sønderborg. At de gamle danske bylove tildels havde tyske forbilleder, er en anden sag; det gjaldt også for de middelalderlige stadsretter nord for Kongeåen som i Lund, Helsingborg, Roskilde, København og Viborg. Slesvigs gamle bylov fra ca. 1200 , som er den ældste stadsret i Danmark, byggede sikkert i vidt omfang på vedtægter i forgængeren Hedeby; men den viser også slægtskab med gamle handelsstæder i Rhin-egnene som Dortmund og Soest, hvis stadsretter er skrevet omkring 1150.

Også senere danske rigslove blev $i$ et vist omfang brugt i Sønderjylland. Mellem 1326 og 1460 gjaldt naturligvis tillige de særlige bestemmelser for hertugdømmet eller dele af det, som blev givet af greven af Holsten som landsherre i Sønderjylland. Greverne synes dog ikke at have gjort større indgreb i landsdelens danske retssystem. I hvert fald blev Jyske Lov i 1300tallet oversat til det plattyske sprog, som dengang og indtil ca. 1600 var regeringssproget i Sønderjylland (og Holsten). Jyske Lov brugtes også ganske fast selv på Helgoland, som hørte til Nordfrisland og dermed til Sønderjylland, men havde nogle særlige love, og på Femern, der havde sin egen landret.

\section{Efter reformationen ændres Sønderjyllands retsforhold}

I de første tiår efter Christian 2.'s fald skete der flere ting, som tilsammen kom 
til at bevirke en væsentlig begrænsning af det danske retsgrundlag i Sønderjylland.

Reformationen begyndte i Sønderjylland allerede i 1522 - i Husum - og navnlig 1525 i Haderslev provsti. Den fik sin endelige form 1542 ved en tyskpræget kirkeordning, fælles for hertugdømmerne Slesvig og Holsten, med udelukkende tysk kirkesprog op til Flensborg fjord uden hensyn til det danske - på vestkysten frisiske - folkesprog. Det berørte også retsudviklingen, da man nu ikke længere brugte den katolske kirkes kanoniske ret og i høj grad begrænsede de kirkelige domstoles virkefelt. Til gengæld begyndte man ligesom nord for Kongeåen og i de andre protestantiske lande at bruge det Gamle Testamentes retsregler (Mose Lov), især i straffesager; det gav indpas for regler som »øje for øje, tand for tand, liv for liv«. I Sverige blev Mose Lov ligefrem ved lov gjort til gxldende svensk ret.

Da den jyske højadel 1523 undsagde Christian 2. og indkaldte hans farbror hertug Friedrich på Gottorp som ny konge, havde kong Christian også i Sønderjylland støtte hos borgere og bønder - forresten da også fra nogle adelsmænd - ligesom på Sjælland, i Skåne og Vendsyssel m.m. På det gamle sønderjyske landsting Urnehoved samledes bønderne for at støtte kongen; herredsfoged Nis Henriksen, der talte hertugens sag, blev jaget væk med pile i sin kappe. Men da Christian drog af lande, fik Friedrich magten som konge i Danmark og Norge og eneherre i Holsten og Sønderjylland. Aret efter ophævede han tinget på Urnehoved og erstattede det med en årlig landdag for Sønderjylland, i første omgang i Flensborg. Her var bønderne ikke med, og landdagen beherskedes af adelen, altså holstenerne. Efter reformationen forsvandt også kirkens repræsentanter fra landdagen, som nu dirigeredes helt af det slesvig-holstenske ridderskab og oftest blev slået sammen med landdagen for Holsten. - Syd for Kongeåen havde adelen i forvejen fået domsmagt (hals- og håndsret) på sine godser, og det begrænsede den sønderjyske almues medvirken $\mathrm{i}$ retsplejen til de resterende herreds- og byting.

Hertug Friedrich var udpræget holstensk og lærte vist aldrig at tale ordentligt dansk (det er tankevækkende, at kong Frederik 9. var den første af vore 9 Frederik'er, som var døbt Frederik og ikke Friedrich). Også som konge blev Frederik 1. boende på sit kære Gottorp, hvorfra han styrede begge hertugdømmer i deres helhed gennem sit tyske kancelli. Landet nord for Kongeåen styredes derimod fra København gennem rigsrådet og kongens danske kansler. Denne deling af styret fastholdtes også, da sønnen Christian 3. fik København som fast residens, blot sådan, at Tyske Kancelli flyttedes fra Gottorp til Slotsholmen i København. Fra 1536 styrede kongen af Danmark altså det danske hertugdømme Sønderjylland (eller sin del af det) fra 
Danmarks hovedstad København, men gennem et tysk kontor og på tysk sammen med det tyske Holsten.

Christian 3.'s endelige deling af de to hertugdømmer med hans brødre i 1544 betød også en deling af retsvæsenet. Gottorp blev påny regeringssæde, nu for hertug Adolf, hvis kansler og hofret fik opsynet over de gottorpske dele af Sønderjylland og Holsten. De kongelige dele af hertugdømmerne lå fortsat under kongens Tyske Kancelli i København, men fik nu en melleminstans i et kongeligt regeringskancelli i Glückstadt i Holsten. Hele retsvæsenet både $\mathrm{i}$ de kongelige og de hertugelige dele af Sønderjylland styredes altså fortsat sammen med holstenske områder - af tyskere og på tysk. Det kunne ikke undgå at få følger.

Alligevel gjaldt dansk ret dog foreløbig ret uindskrænket ned til Ejderen. Og de tre første danske konger efter reformationen havde en så stærk stilling, at deres vigtigste nye love i vidt omfang brugtes i Sønderjylland, selv om de ikke direkte var givet for hertugdømmet. Det var love af stor praktisk betydning, både Christian 3.'s recesser, Frederik 2.'s gårdsret, hans søret og hans agteskabsordinans og endelig Christian 4.'s store reces af 1643. Under Christian 4. autoriseredes 1592 en ny plattysk udgave af den ærværdige Jyske Lov til brug i Sønderjylland; den indeholdt også en oversættelse af Christian 3.'s og Frederik 2.'s recesser. Haderslev amts herredsretter brugte dog en dansksproget udgave af 1590 .

\section{Syd for Ejderen romerret og kejserret}

Sydpå var oldtidens romerret påny kommet til ære og værdighed. Den var oprindelig skabt i det romerske kejserrige i de første århundreder efter Kristi fødsel af meget dygtige jurister ud fra dagliglivets praktiske behov og var siden samlet til et stort lovværk under den østromerske kejser Justinian omkring år 550. Denne Corpus Juris var gået af brug, men blev taget op igen i middelalderen ved de universiteter, der da opstod i Vesteuropa, først $\mathrm{i}$ Bologna. De tyske kejsere herskede på den tid over store dele af Italien og følte sig - gennem Karl den Store - som arvtagere efter de gamle romerske kejsere. Da rigskammerretten i Wetzlar oprettedes i 1495, anerkendtes romerretten i den fornyede skikkelse som galdende "kejserret “. Det gamle germanske retsvæsen var mange steder gået i forfald, og i det vidtstrakte rige med mange uensartede lande var der trang til et samlet retssystem. Hertil brugte man den gamle romerret, der ganske vist var blevet til over 1000 år tidligere og $\mathrm{i}$ et helt andet samfund; derfor udvikledes den videre ved fortolkning og ny lovgivning. Med de universitetsuddannede fagjurister slog den tysk-romerske ret også igennem i Nordtyskland, derunder i Holsten, men 
i første runde ikke længere; ved Ejderen måtte den gøre holdt. Sønderjylland var stadig et dansk len og hørte ikke til det tyske kejserrige. I tilknytning til denne kejserret udgav kejser Karl 5. i 1532 en ny straffelov (Halsgerichtsordnung) for hele riget med mange regler om retsplejen og en række nye, strenge straffebestemmelser. Den ny lov, som efter sin giver kaldtes Carolina, henviste iøvrigt til galdende lokal ret. Den var allerede før $1600 \mathrm{i}$ fast brug $\mathrm{i}$ Holsten ved siden af den gamle Sachsenspiegel.

I Danmark var man mindre energisk end tyskerne med at dyrke teoretisk jura (det gælder også $\mathrm{i}$ nutiden). Vi havde $\mathrm{i}$ middelalderen en hel række dygtige kirkefolk, som samtidig var fremragende retslærde, f.eks. biskop Gunner i Viborg, som var med til at skrive Jyske Lov. Efter reformationen faldt denne gruppe retslærde væk, og det varede længe, før der påny kom gang $i$ dansk retsvidenskab; men gennem praksis skabtes der ny ret $i$ betydeligt omfang ved domme afsagt af Kongens retterting. Når det kneb at finde hjemmel i dansk ret for en fornuftig afgørelse, skete det, at dommen henviste til en egnet udenlandsk regel som eksempel på en rimelig måde at afgøre dette forhold på. Fra 1500- og 1600-tallet kendes flere danske retssager, hvor man frejdigt dømte med henvisning til »kejserretten «. Nogen stor direkte anvendelse af tysk og romersk ret blev det dog aldrig til i Danmark. Romerretten fik betydeligt større indflydelse i Sverige, navnlig ved påvirkning fra de baltiske og nordtyske provinser, Sverige erobrede dengang. Selve Sverige lå jo ikke direkte op til Tyskland og behøvede derfor ikke i samme grad som danskerne at være på vagt over for en stærk tysk indflydelse.

\section{Fra ca. 1600 begyndte tysk ret at sive over Ejderen}

I Sønderjylland opstod der efterhånden forskellige revner, hvor tysk-romersk ret begyndte at trænge ind.

I hertugens område i det sydvestlige Sønderjylland blev der i nogle lokale retsordninger givet udtrykkelig hjemmel til at bruge tysk romerret, når områdets sædvanlige retsregler ikke slog til (det kalder man subsidiær gyldighed). Begrundelsen var, at romerretten var "grundet i naturlig billighed" som "det skrevne udtryk for sund fornuft" (det var nu ikke altid rigtigt). Det skete først for halvøen Ejdersted, da den fik en ny landret 1591, skrevet på Gottorp. Det fik også virkning for de to nye købstæder i Ejdersted, Tønning og Garding, og siden for en stor del af de koge, som blev inddiget i de næste 200 år på den slesvigske vestkyst, helt op til Frederikskog og Rudbølkog, dẹ kom med til Danmark i 1920. Et ganske lille hjørne af det nuværende Danmark har altså haft romerret som gældende ret. Også byerne Husum og Frederiksstad fik en lignende hjemmel for subsidiær brug af tysk- 
romersk ret ved deres stadsretter af 1608 og 1633. Sådan hjemmel var der ikke i Egernførdes (nye) stadsret af 1635; men den indeholdt enkelte regler, som er taget fra romerretten.

Romerretten fik også delvis indpas på en anden led, nemlig for størstedelen af den tyske overklasse i Sønderjylland. Til at afgøre alle sager mod adelige og gejstlige oprettedes en særlig domstol, kaldet landretten. Dens "landretsordning " af 1573 henviste til tysk-romersk og saksisk ret, hvilket var ret naturligt, da ridderskabet var næsten rent holstensk og en meget stor del af præsterne kom sydfra. En revideret landrets-ordning for begge hertugdømmer, udgivet af kongen og hertugen 1636, skelnede dog klart mellem kap. II om hertugdømmet Slesvig, hvor man skulle dømme efter Jyske Lov og gammel sædvane, og kap. III om hertugdømmet Holsten, hvor sagerne skulle afgøres efter holstenske sædvaner, saksisk ret og subsidiært efter romerretten. Men samme år udgav de to landsherrer $\mathrm{i}$ fællig en anden forordning for begge hertugdømmer om oprettelse af en specialdomstol (consistorium) for adeliges og kirkefolks ægteskabssager og visse straffesager mod adelige; deri blev det direkte påbudt at bruge kejser Karls "pinlige halsretsordning “, altså klar hjemmel for brug af tysk straffelov også i Sønderjylland, men kun for en snæver befolkningsgruppe.

I samme tidsrum indførtes også den nye tyske skik med universitetsuddannede advokater i retssager. De kom ind i Holsten sammen med brugen af Carolina. I Sønderjylland dukkede allerede før år 1500 af og til tyskuddannede advokater op, derimellem enkelte kejserlige notarer, og landretsordningen tillod at bruge advokater og prokuratorer uden at udelukke udlændinge. I kongeriget klarede man sig endnu næsten uden studerede jurister, da de gamle danske retsregler var mere enkle og overskuelige end det brogede retssystem i Tyskland. Den danske retspleje kunne derfor fortsat administreres af forstandige bønder og borgere (som det den dag i dag foregår med de fleste straffesager i England, der afgøres af fredsdommere). Først 1638 var man også i kongeriget så vidt, at der kom en kongelig forordning om prokuratorer.

I Sønderjylland fik advokaterne en stærkt voksende indflydelse, og de var alle tysk uddannede. Derfor kendte de ofte meget lidt til dansk-slesvigske love og regler og kørte i mange tilfælde også i Sønderjylland glad løs med tyske retsplejeregler i stedet for reglerne i Jyske Lov (altså bestemmelser i landretsordningen og Carolina), med strafferegler fra Carolina og også tildels med romerret, selv om den $i$ begyndelsen normalt blev afvist. I det lange løb satte tysk jura et ret stærkt præg på retsforholdene i Sønderjylland, navnlig efter 1700 , da de fleste dommerembeder blev besat med tysk uddannede jurister. 
Senere har enkelte tyske forfattere hævdet, at den tyske romerret i sin helhed blev gældende også i Sønderjylland ved landrets-ordningen af 1636; de ser helt bort fra, at bestemmelsen om brug af romerret netop kun fandtes $i$ kapitlet om Holsten. Idag er der dog nogenlunde enighed om, at romerretten i Sønderjylland kun fik gyldighed i meget begrænset omfang uden for retsplejen og strafferetten og bortset fra hjørnet med Ejdersted, Husum osv. Inden for civilretten (det, man kalder borgerlige retssager) ansås romerretten ikke for galdende i Sønderjylland; den brugtes kun som forbillede, men fik dog stor betydning for retsudviklingen ved den tankegang, der var skolet ved studiet og brugen af romerret, hvorfra vi har fảet en del begreber, der idag føles som god gammel nordisk ret. Dette gælder også nord for Kongeåen, men den romerretlige påvirkning blev naturligvis stærkere $\mathrm{i}$ hertugdømmet på grund af de mange tyske jurister, der optrådte i retssalene.

\section{Særligt om hekseprocesser}

Som eksempel på den stærkere indvirkning sydfra i Slesvig i forhold til det øvrige Danmark kan nævnes heksebrændingerne. Ordet heks kom for resten ret sent $\mathrm{i}$ brug nord for Ejderen; det kan på tysk bruges både om en kvinde (Hexe) og om en mand (Hexer). I Norden har vi de gamle ord trolddom, trold, troldkvinde og troldmand; allerede $\mathrm{i}$ tidlig middelalder kendes nordiske sager mod troldfolk, i nogle tilfælde med bålstraf, og Jyske Lov fik længe efter Valdemar Sejr en tillægsparagraf om trolddom. Den egentlige heksejagt startede med en tysk bog af 1487, og Carolina fastsatte bålet som straf for skadelig trolddom. Efter reformationen flammede heksebålene over hele Europa, ikke mindst $i$ de protestantiske lande og først, længst og mest $i$ Tyskland; det sidste tyske heksebål blev afbrændt 1775. I selve kongeriget Danmark brændtes den første heks 1540 på Møen og den sidste 1693. For Sønderjylland ligger de heksebål, jeg har kunnet opspore, fra 1543 (på Als) til 1686 (i Angel, på godset Runtoft). I Holsten brændte det sidste heksebål 1687. Denne rædsel sluttede altså nogenlunde samtidig i monarkiets forskellige dele. - Som "bevismiddel i trolddomssager brugtes i Tyskland vandprøven; den kendes for resten langt tilbage og brugtes mod forbrydere allerede i det gamle Assyrien og i Babylon under Hammurabi. Den brugtes også i mange hekseprocesser i Holsten og Sønderjylland, derimod sjældent nord for Kongeåen, hvor jeg kun har fundet den anvendt i Rugårds birk. I Sønderjylland har jeg optalt ca. 45 sager med heksebål; men der var nok mange flere. I mange af sagerne blev der brændt flere kvinder, i et tilfælde en troldkarl. Ordet heks har jeg set anvendt i Sønderjylland fra 1635 , mens det $i$ kongeriget først brugtes i 1693. På Als slap en troldkone, der havde haft 
forbindelse med en sort dreng, kaldet Liden Trold, i 1670 med halshugning. I årene omkring 1600 dømtes en del flensborgske hekse. Flere af dem brugte trylleord på dansk, nogle med afslutningen "I Jesu navn, Amen«. En af disse arme kvinder tilstod, at hun havde haft omgang med »en tyk, kold patron «, som talte dansk og hed Nis.

Han var måske i familie med vor julenisse. Kun få danske tænker på, at nissen må være sønderjyde. Ordet Nis kommer fra den hellige Nicolaus ligesom den hollandske og engelske Sanct Claus; nord for Kongeåen blev Nicolaus til Niels. I Sønderjylland kom den lille mand til at hedde både Nis og Puk eller Nis Puk, og han var dansk. Et gammelt ord i Sydslesvig siger: "Nissen vil ikke over Ejderen “, altså til Holsten og Tyskland; nissen kendes dog også i Ditmarsken, som har haft en del indvandring nordfra. Navnet Puk gik med anglerne til England, hvor den lille fyr kaldes Puck, mens navnet Nis som "nissen " har bredt sig over hele Danmark. - Nå, det var et sidespring fra retshistorien.

\section{Ophævelsen af dansk lenshøjhed over Sønderjylland}

Selv om lovgrundlaget i Sønderjylland i 1600-tallet for den brede befolkning fortsat var dansk-slesvigsk bortset fra sydvesthjørnet, var der altså inden 1650 lagt grund for et stærkt indbrud af tysk jura og retspleje.

Muligheden herfor øgedes i høj grad ved den ulykkelige Roskilde-fred 1658, hvor Danmark ikke blot mistede hele Skåne, Halland og Blekinge til Sverige, men også måtte opgive suveræniteten over den hertugelige del af Sønderjylland, da hertugen på Gottorp, som var svigerfar til Karl 10. Gustav, havde indgået forbund med Sverige mod Danmark. Denne store gevinst for Gottorp opretholdtes mærkeligt nok ved fredsslutningen 1660 efter Sveriges nederlag og den svenske konges død. At København holdt under den lange svenske belejring, så krigen endte med, at Danmark overlevede, skyldes iøvrigt bl.a. en hel række fremragende sønderjyders modige og dygtige indsats, især ved forsvaret af hovedstaden (Hans Nansen, Hans Schack, Claus Ahlefeldt fra Gelting og Frederik Ahlefeldt fra Maslev i Svans samt de to snilde og tapre ridefogder Lorenz Tuxen og Hans Rostgaard). Det er værd at notere, at hovedstadens og rigets redning i den yderste nød for en stor del skyldtes dels en del gæve folk fra Sønderjylland, grænselandet i sydvest, dels Svend Gønge og hans folk i Sydsjælland og nogle kompagnier gønger i København, altså folk fra Gønge herred i Skåne, fra grænsen mod nordøst. Når hertugen blev suveræn i sin del af Sønderjylland, måtte det samme gennemføres også for kongens dele af hertugdømmet (derimod var der jo slet ikke tale om at fjerne Holstens lenstilknytning til Tyskland!). Danmark 
mistede altså lenshøjheden over hele Sønderjylland. Dette stod både for samtiden og for eftertiden i skygge af tabet af de kernedanske Skåne-lande, $1 / 3$ af kongeriget; Slesvigs forbindelse med riget var jo forlængst blevet noget løs. Alligevel var det et skridt, som fik meget alvorlige følger. Opgivelsen af Danmarks højhedsret over det danske hertugdømme Sønderjylland betød ganske vist ikke, at det blev et led af det tyske kejserrige. Men Sønderjylland kom statsretligt til at svæve for sig selv - ved siden af Danmark, og det var stadig i det daglige nøje forbundet med det tyske Holsten, hvis overklasse fortsat regerede den slesvigske befolkning. Jeg har en fornemmelse af, at danske historikere ikke har tillagt opgivelsen af højhedsretten over Sønderjylland alt for stor betydning. Vi danske hænger os ikke så meget $\mathrm{i}$ det formelle. Det kan ofte være praktisk; men til andre tider kan det være skæbnesvangert, hvis man overser, at der af det formelle kan følge solide realiteter.

Tyske jurister og historikere har lagt betydeligt større vægt på denne vigtige ændring i Sønderjyllands statsretlige stilling. Den fik også indgribende betydning for den indre retsudvikling $\mathrm{i}$ hertugdømmet; det er ganske tydeligt, når man studerer slesvigske domme fra de følgende 100 år. Flere ting viser, at både Frederik 3. og Christian 5. var klar over rækkevidden af denne afståelse mod sydvest. De stræbte i hvert fald begge efter at omgøre dette farlige skridt eller dog afbøde dets virkninger. Frederik 3. befalede i sit sidste regeringsår, at Tyske Kancelli ikke længere måtte beskæftige sig med sager fra kongens dele af Slesvig, og at disse sager skulle overtages af Danske Kancelli. Derfor fik Sønderborg i 1670 kongelig bekræftelse på sine privilegier gennem Danske Kancelli og på dansk, noget helt nyt. Denne helt naturlige nyordning blev dog væltet samme år, efter at en ny kongelig instruks havde lagt de slesvigske sager vedrørende kongens og hertugens fællesregering $\mathrm{i}$ hertugdømmet (over adelige områder m.m.) under Tyske Kancelli. Det stred tilsyneladende ikke mod befalingen fra 1669; men Tyske Kancelli benyttede lejligheden til påny at sætte sig på alle kongens slesvigske sager - eller meget svagt over for kongens holstenske embedsmænd (Danske Kancelli må have sovet eller været ligeglad). Dette forhold ændredes heller ikke, da Griffenfeld i sin tid som rigskansler flyttede udenrigstjenesten fra Tyske til Danske Kancelli, hvilket Tyske Kancelli også fik "rettet " efter Griffenfelds fald. - Når man selv har gjort tjeneste i Den Røde Bygning, aner man bag disse manøvrer den indre magtkamp, som den dag i dag kendes mellem forskellige ministerier og departementer.

Christian 5. understregede, at Sønderjylland ikke var noget tysk land. Over sydporten til fæstningsbyen Rensborg, ved grænsen til det tyske rigslen Holsten, lod han opsætte en sten med en latinsk indskrift, som kunne forstảs 


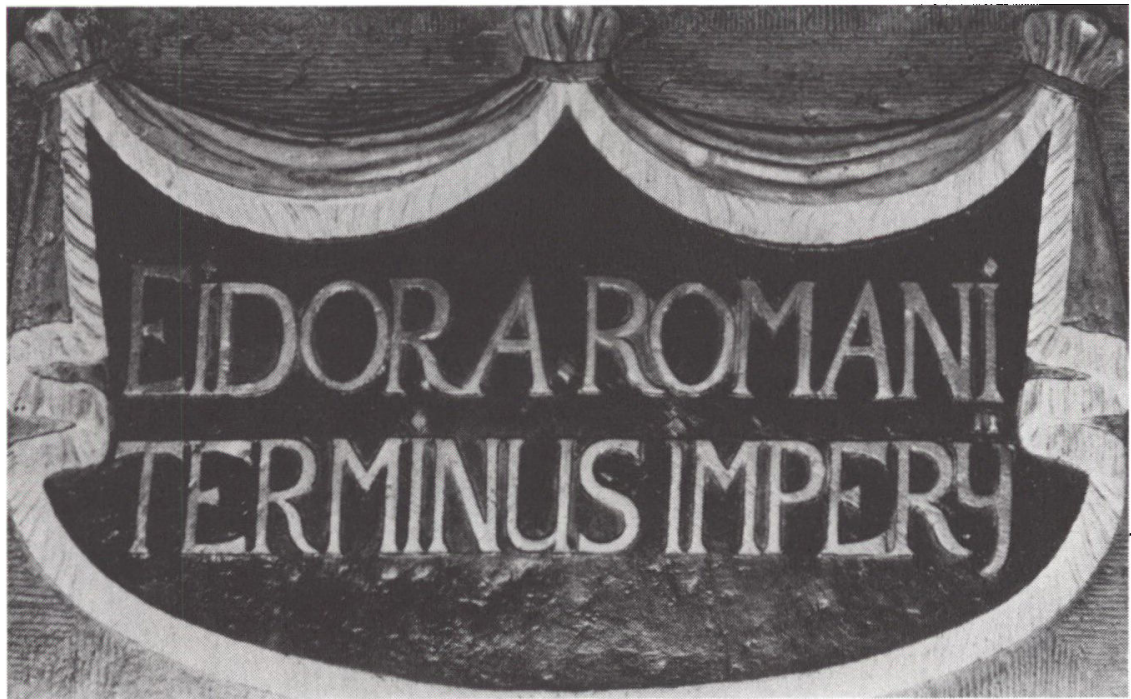

Ejderstenen. - Som et udtryk for sin vilje til at bevare Sonderjylland som et dansk land lod Christian 5. ca. 1690 denne tavle opsatte over én af Rendsborgfastningens porte pá gransen til det tyske rigsland Holsten. Indskriften betyder: Ejderen er det (tysk-)romerske riges granse. Ejderstenen findes nu $i$ Tojhusmuseet $i$ Kobenhavn.

af alle, der havde studeret romerret: "Eidora Romani Terminus Imperii« (Ejderen, det romerske riges grænse). Hertil og ikke længere gjaldt kejserretten. Han havde et meget dårligt forhold til den nye hertug Christian Albrecht, der under Københavns belejring havde opholdt sig i Karl Gustavs lejr ved Brønshøj som Danmarks fjende. Da kongen i 1684 fik en anledning til det, besatte han hertugens dele af Slesvig og forenede dem med de kongelige områder af hertugdømmet. Derefter oprettede han et særligt justitskancelli på Gottorp som kongeligt regeringskontor og overret for hele Sønderjylland og understregede, at der i hertugdømmet skulle dømmes efter Jyske Lov. Den helt nye Danske Lov af 1683 blev altså ikke gjort til almindelig landslov også $\mathrm{i}$ hertugdømmet; men kongen nedsatte en kommission til at udarbejde en ny lovbog for Slesvig i stedet for Valdemar Sejrs lov, der nu var over 400 år gammel. 5 år efter måtte kongen imidlertid under pres fra Sverige, Tyskland og Frankrig igen udlevere de gottorpske områder til hertugen. Så var Sønderjylland tilbage under den efterhånden tilvante delte styreform, hvor styret var tysk og overvejende udøvedes af holstenere. Scenen var ved at vare klar til det næste store skift i landsdelens retsudvikling. 
Efter 1683 gjaldt syd for Kongeåen stadig Jyske Lov, men under stigende pres fra tysk jura

Bortset fra Christian 5.'s 5-årige eneherredømme over Sønderjylland pegede hovedlinien i hertugdømmets udvikling gennem 1600-tallet klart i retning af mere tyskpræget jura. Det ses også af landsdelens forhold til Danske Lov af 1683. Denne velskrevne lov, som var udpræget dansk-nordisk og meget lidt påvirket af romerret, blev givet for kongeriget Danmark (altså nord for Kongeåen), mens søsterriget Norge fik sin egen Norske Lov 1687; Norske Lov gælder forøvrigt stadig på Færøerne, der jo var et norsk land til 1814. De tidligere recesser fra Christian 3., Frederik 2. og Christian 4. var heller ikke givet direkte for Sønderjylland, men blev dog som danske rigslove uden synderlig diskussion faktisk brugt også $\mathrm{i}$ hertugdømmet, som var et dansk len. Nogle retshistorikere skriver, at dette skete i kraft af en retssædvane; men de nævner ikke, hvorfor den sædvane ikke kom til også at omfatte Danske Lov. Forklaringen er vel ganske enkelt, at Sønderjylland efter 1658 ikke længere var under dansk overhøjhed, men et suverænt hertugdømme. Danske Lov gjaldt altså principielt ikke syd for Kongeåen; der var dog vigtige undtagelser. Den gjaldt naturligvis fuldt ud i de norrejyske enklaver $\mathrm{i}$ Vestslesvig; de hørte jo med til kongeriget og lå under Viborg landsting. Øerne Als og \#rø var slesvigske, men hørte under Fyns stift og tilhørte dengang endnu forskellige yngre grene af kongeslægten som små hertugdømmer; disse var ikke omfattet af suverænitetsaftalen 1658 og ansås derfor stadig som danske len. Følgelig blev Danske Lov i dens fulde omfang taget $i$ brug på disse to øer.

Desuden blev Danske Lovs 2. bog om gejstligheden også anvendt $\mathrm{i}$ Haderslev provsti (Tørning len), der hørte under bispen i Ribe, ikke til Slesvig stift.

Danske Lovs 4. bog om søretten anvendtes ligesom tidligere Frederik 2.'s søret almindeligt i Sønderjylland, herunder i Slesvig by. De sydligste byer Rendsborg, Husum, Tønning, Burg og Egernførde brugte dog lybsk søret ligesom Tønder (hvis denne by endnu havde søsager).

Ellers gjaldt som hovedregel stadig Jyske Lov, undertiden kaldet "den gamle danske lov « (til forskel fra den nye D.L.). Den virkede nu meget forældet, selv om det delvis var afhjulpet ved recesserne og ved en del nye forordninger for Slesvig. Der var derfor en ret stærk trang til at bruge mere moderne ret, og nu begyndte virkningen af de tyskuddannede advokater at vise sig, På grund af hertugdømmets ejendommelige'statsretlige stilling er det ikke mærkeligt, at juristerne i vidt omfang søgte at bruge den jura, de havde lært på tyske universiteter. I et stigende antal tilfælde begyndte advokater at 
diske op med lange skriftlige indlæg på tysk - tilmed på Luthers højtyske, der nu var regeringssproget $i$ hertugdømmerne - isprængt en hel del mere eller mindre korrekt latin og med henvisninger til tysk-romerske retsregler og sprænglærde tyske forfattere. Det var det rene volapyk for almindelige sønderjyder, hvad enten de talte dansk, frisisk eller plattysk.

Man finder i sønderjyske tingbøger i 1600-tallet og ind i 1700-tallet en hel del klager fra danske slesvigere over, at de ved herredstinget bliver mødt af en modpart med advokat, og at de ikke forstår advokatens tysk og latin og hans mange henvisninger til fremmed ret. I enkelte tilfælde afviste herredsfogden de lærde indlæg og en sjælden gang endda advokaten selv på grund af »utilbørlig skrivemåde«. Værre var det, at de lægdommere, som dengang medvirkede ved herredsretterne, oftest uden juridisk bistand, heller ikke forstod al den juridiske snak, selv om de kunne læse tysk. Herredsfogden var ligesom nord for Kongeåen normalt en dygtig bonde, og købstadens byfoged var oprindelig en solid borger. Men allerede i 1500-tallet begyndte man at besætte byfogedstillingerne med landsherrens egne tjenere, senere også herredsfogedposterne. Også de andre folkelige tingmænd - sandemænd og nævninger - blev trængt i baggrunden. I 1600-tallet begyndte man at besætte fogedstillingerne i Sønderjylland med fagjurister ligesom i Holsten. I kongeriget skete dette 100 år senere. Først 1736 indførtes der overhovedet en juridisk embedseksamen ved Københavns universitet; til den blev der ikke blot undervist $\mathrm{i}$ romerret og naturret, men også $\mathrm{i}$ dansk og norsk lovkyndighed, noget helt nyt. Det er næppe tilfældigt, at denne ordning $i$ København blev gennemført af en mellemslesviger, den dygtige Andreas Hojer, præstesøn fra Karlum lidt syd for 1920-grænsen.

En kongelig forordning af 1685 og en hertugelig af 1710 forbød at bruge kejserlige notarer i Slesvig, nok mest for at beskytte landsdelens egne advokater; men 1708 forbød hertugen helt brugen af advokater ved herredsting. Alligevel trængte advokaterne ind overalt, og i Sønderjylland fik de en særlig magt netop på grund af hertugdømmets indviklede retsforhold, som de selv bidrog til at gøre endnu mere uoverskuelige. I byerne var retssproget tysk allerede før 1600, ligeså i Sydslesvigs herredsretter trods dansk og frisisk folkesprog. I en del nordslesvigske landdistrikter holdt dansk retssprog længere, men også her forsvandt dansk fra tingbøgerne i løbet af 1700-tallet. I takt dermed mistede lægdommerne det meste af deres indflydelse, især i Nordslesvig, hvor de normalt slet ikke kunne følge med i de tyske indlæg.

Retsplejens forfald i Sønderjylland viste sig også ved, at amtmanden efterhånden overtog en hel del af afgørelserne både $\mathrm{i}$ straffesager og $\mathrm{i}$ borgerlige sager; i andre tilfælde virkede han som en slags overinstans. Det 
skete først i herrederne, senere også i byerne - undtagen den selvbevidste handelsstad Flensborg. På dette område sås tydeligt forskellen over for de kongerigske enklaver, hvor herredsfogden bevarede sin stilling som selvstændig dommer.

Også en anden tysk skik optog man i Sønderjylland efter holstensk forbillede, nemlig at indhente vejledende udtalelser fra tyske universiteter $i$ særlig vanskelige retssager. En del af disse udtalelser, der i mange tilfælde afgjorde sagen, blev hentet fra universitetet i Kiel, som hertugen oprettede i 1665, og som bidrog vasentlig til at fortyske Sønderjylland (ligesom det af forbundsfællen Sverige få år efter oprettede universitet i Lund var med til at gøre det danske Skåne svensk). Men i mange tilfælde rådspurgte man også andre tyske universiteter, som naturligvis udtalte sig ud fra tyske retsregler, da de ikke kendte Sønderjyllands gamle danske ret.

\section{3 forsvandt gottorperne, men Sønderjylland blev ikke indlemmet}

Det sønderjyske retsvæsen blev altså på mange måder trukket stadig længere i tysk retning. Men så kom den stund, Danmark havde ventet på siden 1658, da det omsider lykkedes at drive den gottorpske hertugslægt helt ud af Sønderjylland. Under den store nordiske krig optrådte Gottorp påny som Sveriges faste allierede og Danmarks fjende, og denne gang kunne den danske konge slå til og gøre ende på den stadige trussel i ryggen på Danmark. 1713 lod han sine tropper besætte hertugens sønderjyske områder, og ved fredsslutningen 1720 blev hans stilling som eneherre i Sønderjylland fastslået. Nu skulle man tro, at tingene endelig kom på plads, så Sønderjylland igen blev en dansk provins som før 1326, 1460 og 1658, og det forkvaklede styre i landsdelen kunne afskaffes. Det er også helt tydeligt Frederik 4.'s ønske. I 1713 måtte han dog nøjes med en foreløbig ordning, indtil der kunne sluttes fred. Ligesom ved Christian 5.'s inddragelse af de hertugelige områder i 1684 oprettedes der på Gottorp en midlertidig regeringskommission for Sønderjylland. Den skulle også være overret for både de kongelige og de gottorpske dele af hertugdømmet og skulle fortsat bruge Jyske Lov som almindelig landret, "indtil vi forordner noget andet “. Man brugte dog stadig de tyske procesregler fra landretsordningen af 1636; men kongen ønskede at indføre appel til den danske Højesteret i slesvigske sager. Det prøvede han 1718 at gennemføre $i$ en kaperi-sag fra Helgoland; men trods gentagne påbud fra kongen nægtede de sagsøgte helgolændere at møde i København og holdt fast ved, at de kun skulle møde for overretten for Slesvig. 1722 gav kongen efter og lod sagen sende til Gottorp. - I en røverisag fra Husum amt lod kongen i 
1720 indhente udtalelser fra Københavns universitets teologiske og juridiske fakulteter, skønt overretten i forvejen havde skaffet en erklæring fra Kiels juridiske fakultet. Jeg sad $i$ landsarkivet på Gottorp med denne sags papirer og faldt der over et ret sensationelt dokument. Det var ikke bare på dansk i modsætning til alle sagens andre papirer; det var en votering i denne slesvigske sag i Danmarks Højesteret efter anmodning fra kongen (som også afgjorde sagen som indstillet af Højesteret). Det skete af og til, at kongen pålagde Højesteret at afgive en udtalelse om en sag efter at have drøftet den $i$ lukket møde; men dette er det eneste kendte eksempel før 1920 på, at Højesteret har behandlet en slesvigsk sag.

For Frederik 4. fik ikke indlemmet Sønderjylland i Danmark. 1713 havde han magt til at gøre det og ville det også. Men i de 7 år, der gik, til freden blev sluttet, kom ridderskabet atter til kræfter; det udgjorde fortsat en enhed tværs over Ejderen og ville ikke opgive den magtstilling i Sønderjylland, det havde oparbejdet i 3-400 år. Kongehusets gamle betroede rådgiver, sakseren v. Breitenau, der boede i Lübeck, fremhævede i en erklæring af januar 1721 over for fordelene ved at indlemme Sønderjylland i kongeriget en hel rakke modargumenter, navnlig de store vanskeligheder, kongen ville få med ridderskabet, men også at det kunne være praktisk for kongehuset at have Slesvig som et særligt område til eventuel forsørgelse af yngre sønner, hvilket for kongerigets vedkommende var forbudt $\mathrm{i}$ kongeloven; han glemte at nævne, at også en sådan brug af hertugdømmet kunne støde på stærk modstand hos det ridderskab, han netop havde fremhævet som den største vanskelighed ved en indlemmelse (i kongeriget var kongen jo efter 1660 fri for det adelige rigsråd som modspiller). Andre rådgivere gik ind for fuld indlemmelse $\mathrm{i}$ overensstemmelse med kongens eget onske; men $\mathrm{i}$ den givne situation savnedes der en stærk og klartskuende dansk statsmand til at føre dette synspunkt igennem. Afgørende blev det nok, at Frederik 4. og hans hof var langt mere tyskpræget end f.eks. Christian 4. og 5., og at kongen netop $i$ de måneder var stærkt optaget af en helt anden sag; straks efter sin dronnings død indgik han regulært ægteskab med Anne Sofie Reventlow og gjorde hende til dronning - hvilket medførte yderligere fortyskning af hoffet. Tyske Kancellis embedsmænd støttede naturligvis v. Breitenaus erklæring (de var jo ikke interesserede $i$ at afgive et stort sagsområde og dermed en del af deres magt og mulighed for gode stillinger). Enden blev, at kongen på indstillingen fra kancelliet skrev, at indlemmelsen af Sønderjylland i kongeriget skulle gennemføres "lidt efter lidt «, idet hertugdømmet i første omgang kun skulle "genforenes med kronen “, et noget uklart udtryk, som danske og tyske siden har fortolket helt forskelligt. Der gennemførtes i september 1721 en arvehyldning på Gottorp slot ved repræsentanter for de slesvigske stænder, 
og Frederik 4.'s navnetræk anbragtes på alle offentlige bygninger i hertugdømmet.

Men kongens titel var stadig "Konge til Danmark og Norge, hertug til Slesvig, Holsten osv.«, altså med Slesvig som et særligt område ved siden af Danmark. Det blev også resultatet af det hele; for man nåede ikke videre, heller ikke lidt efter lidt. Den eneste væsentlige faktiske ændring i Sønderjyllands styreform var altså det, der allerede skete i 1713, nemlig en genforening af de gottorpske områder med den kongelige del af hertugdømmet og så oprettelse af nogle fælles slesvigske institutioner uden forbindelse med Holsten. I de første år var der dog tilløb til at gå videre $\mathbf{i}$ dansk retning. Alle slesvigske domstole fik ordre til at anskaffe en ny udgave fra 1717 af Jyske Lov i tysk oversættelse med udførlige noter. Kongen gentog også forbudet mod at bruge fremmede notarer i Sønderjylland; det blev dog ikke brugt til at udelukke holstenere og bortfaldt, da der blev udstedt en ny advokat-ordning i 1740 . Denne forbød derimod at henvise til fremmed ret eller at bruge usædvanlige latinske vendinger - med lige så lidt virkning som tidligere forskrifter af den slags. 1746 blev det forbudt at indhente udtalelser fra tyske universiteter $i$ slesvigske retssager.

\section{Efter 1720 slog fortyskningen af retsvæsenet igennem}

Gentagne forslag om at gennemføre Slesvigs indlemmelse i kongeriget eller dog at udvide Danske Lovs område til også at omfatte dette hertugdømme, at indføre appel til den danske Højesteret eller at henlægge alle slesvigske underretter med dansk retssprog under Viborg landsting blev uden resultat. Der blev heller ikke grebet ind over for det tyske retssprog i dansktalende områder. Den tyske linie i retsvæsenet fik igen overhånd. Overretten stod under Tyske Kancelli i København, der var det fælles regeringskontor for Sønderjylland og kongens del af Holsten. Herredsfogedembederne syd for Kongeåen blev efterhånden næsten udelukkende besat med tyske jurister ligesom købstædernes rådstueretter. Skønt en genforening med kongeriget efter 1713 havde været en selvfølge, gik det altså sådan, at ikke bare blev denne genforening forhindret; men der kom for alvor gang i fortyskningen, også inden for retsvæsenet, - netop efter at kongen af Danmark var blevet ene herre i hertugdømmet. Det ses tydeligt på to områder.

Inden for strafferetten havde der allerede tidligere været tilløb til at tage Karl 5.'s "pinlige halsretsordning “ (Carolina) i brug i Sønderjylland; men det var første efter 1720 , at Carolinas strafferegler slog igennem ved de sønderjyske domstole efter klare udtalelser fra overretten og Tyske Kancelli. Overgangen ses tydeligt $\mathrm{i}$ tyverisagerne. Her havde man i Sønderjylland hidtil 
brugt Jyske Lovs regel om, at tyv skulle hænges (undtagen ved første gang begået tyveri under $1 / 2$ marks værdi), suppleret med en bestemmelse $i$ Christian 4.'s reces om, at man i visse tilfælde kunne nøjes med strafarbejde på Bremerholm i København. Nord for Kongeảen gjaldt der nu lidt mildere regler efter Danske Lov. Også i Sønderjylland var der trang til en mildere kurs i mindre alvorlige tyverisager, bl.a. fordi $1 / 2$ mark nu var en hel del mindre værd end i 1241. Dertil kom, at overretten og kancelliet nu ikke blot afviste at bruge Danske Lov, men også de kongelige recesser fra tiden efter reformationen, skønt de var brugt regelmæssigt i Sønderjylland indtil 1713 som en vis modernisering af kong Valdemars gamle lov; det støttedes på ordlyden i instruksen af 1713 for overretten, der sagde, at der i Sønderjylland alene kunne dømmes efter Jyske Lov (skønt meningen hermed var at udelukke tysk og anden fremmed ret, men ikke den hidtidige brug af recesserne eller nye forordninger for Slesvig). - På denne baggrund kom man så uden egentlig lovhjemmel ind på at lade en del tyve slippe med kagstrygning (pisk) samt brændemærke, landsforvisning eller lignende, som det var fastsat i Carolina for tyverier indtil 5 gyldens værdi. Allerede i 1718 slap en kvindelig tyv i Egernførde for dødsstraf under direkte henvisning til Carolina. 1720 gik overretten ind for det samme i to sager fra Husum amt og Als. En sag fra Gram herred endte 1724 efter overrettens indstilling med kagstrygning samt livsvarig forvisning "ifølge den her indførte " Carolina; nu blev det altså sagt lige ud. En lignende sag fra Løgumkloster birk i 1725 fik samme resultat. Hermed var Jyske Lovs hovedrolle $i$ tyverisager forbi, altså bl.a. for at undgå dødsstraffe i mindre grove tilfalde. Men derefter tog man også andre af Carolinas strafferegler i brug, bl.a. nogle straffe, der var meget strengere end efter almindelig dansk ret, og en stor del af Jyske Lovs strafferegler gik af brug; således er mandebod for drab vist ikke brugt i Sønderjylland senere end år 1700. Også mange af Jyske Lovs noget forældede procesregler blev fortrængt af tyske regler, dels bestemmelser i landretsordningen, dels bevisregler m.m. i Carolina, der dog selv havde henved 200 år på bagen. Her kan særligt nævnes torturreglerne, der var langt strengere i Tyskland end i Danmark. I Sønderjylland brugtes tortur derfor i videre omfang end nord for Kongeåen, men sidste gang 1767 (mod nogle jøder i Flensborg); 1770 blev tortur helt forbudt for Slesvig i en forordning, som skyldtes Struense. Det er interessant, at et lignende forbud ikke blev udstedt for Holsten, fordi man der følte sig bundet af Carolina som tysk rigslov; der gik endnu 25 år, før tortur afskaffedes i Holsten.

Geografisk skete der en anden mærkværdighed som følge af kongens overtagelse af herredømme over sønderjyske landsdele. Det drejer sig om Als og Ærø. Her blev Danske Lov som nævnt sat i kraft i sin helhed fra lovens 
udstedelse 1683. Da de 4 små hertuglinier på disse øer gik fallit eller uddøde i løbet af et århundrede, faldt de små len et efter et ubestridt tilbage til kongen. Han lagde dem under den falles administration af hertugdømmet Sønderjylland, altså Tyske Kancelli, og dermed under overretten på Gottorp. Det skete for Als $1730 \mathrm{og}$ for Erø 1750. Overretten afviste nu også for disse rent danske øer brugen af Danske Lov (bortset fra kap. 2 om gejstligheden og kap. 4 om søretten), fordi det stod $i$ instruksen af 1713 , at man i Slesvig kun måtte bruge Jyske Lov; denne blev udtrykkeligt sat i kraft igen i stedet for Danske Lov ved en forordning af 1731 fra amtshuset i Nordborg. Da Jyske Lov nu virkede stærkt forældet, særligt fordi overretten som før omtalt og uden hensyn til Ærø-boernes protest også afviste at supplere den med de senere kongelige recesser, måtte man i straffesager i overensstemmelse med den nu gennemførte praksis i hertugdømmet $\mathrm{i}$ vidt omfang ty til den tyske Carolina, der dog var 150 år ældre end Danske Lov. - Dette virker ekstra unaturligt, fordi Danske Lov i 1700-tallets Europa havde et godt omdømme som en dygtigt skrevet og overskuelig lov $\mathrm{i}$ modsætning til den vidtløftige og indviklede lovgivning $\mathrm{i}$ sydligere lande. Tre af tidens klogeste og mest moderne herskere, Peter den Store af Rusland, Maria Theresia af Østrig og Frederik den Store af Prøjsen, var inde på at efterligne Danske Lovs enkle system i nye love for deres stater, hvilket dog vist ikke blev til noget. Men i Sønderjylland måtte denne gode Lov endelig ikke få indflydelse; det sørgede Tyske Kancelli for. Dansk lovgivnings enkelhed og klarhed fremhævedes forøvrigt også i fortalen til den tyske udgave af Jyske Lovi 1717, hvor denne nu henved 500 år gamle lov pristes på bekostning af Sachsenspiegel og andre landes "Justianeischen, Canonischen und weis nicht was von ungeheuren Gesetz-Büchern«.

Resultatet af den danske konges overtagelse af Als og Ærø fra nogle små halv- eller heltyske hertuger blev altså det groteske, at den moderne og gode Danske Lov blev afskaffet på de to dansktalende øer og overvejende erstattet af en halvgammel tysk straffe- og proceslov. Det passede naturligvis de tyske jurister godt, men måtte virke helt meningsløst på øernes almindelige befolkning. Intet hekseri, kun behændighed.

\section{Begrænset brug af romerret og livegenskab}

Med Carolina kom også anden tysk-romersk ret i brug i Sønderjylland inden for strafferetten og retsplejen; men ellers fik romerretten kun begrænset indpas $\mathrm{i}$ hertugdømmet. Allerede 1604 udtaltes det $\mathrm{i}$ en hertugelig dom $\mathrm{i}$ en gældsbrevssag fra Femern, at en påberåbt romersk retsregel ikke gjaldt $i$ 
hertugdømmet Slesvig og altså heller ikke på Femern; en lignende sætning findes i Femerns konkursordning af 1610. Også på denne oprindeligt vendiske ø gjaldt Jyske Lov subsidiært, altså når øens egen landret ikke slog til. Et indlæg $1724 \mathrm{i}$ en sag ved retten i Nordborg fremhævede, at den almindelige romerret ikke kunne bruges ved en slesvigsk domstol, da Slesvig var uden for Imperium Romanum (det tysk-romerske kejserrige). Tilsvarende udtalelser kan findes i en række andre sager.

I forbindelse med romerretten kan nævnes det særlige retsforhold livegenskabet, dvs. godsejerens fuldstændige ejendomsret over hele befolkningen på godset, noget, der blev almindelig skik allerede før år $1500 \mathrm{i}$ Rusland og Tyskland, ikke mindst $\mathrm{i}$ de forhen slaviske Østersøegne. Det havde sine rødder tilbage til middelalderens trældom og blev i den juridiske tankegang knyttet til forholdene i oldtidens romerrige med slaver og "coloni«. Det brugtes også i Holsten, især på storgodserne i de undertvungne vendiske områder øst for Kiel. Derfra fik livegenskabet senere indpas i det sydøstlige Slesvig (i vor tid Egernførde amt), hvor holstenske stormænd allerede fra middelalderen ejede store godser. Trods forbitret eller fortvivlet modstand blev bønderne i Jernved og det dengang endnu dansktalende Svans tvunget ind i dette umenneskelige system. Det skete uden støtte i Sønderjyllands love, men på grund af den hals- og håndsret (birkeret), den holstenske adel havde fået indført også på sine godser i Sønderjylland. Da underkuede bønder fandt på at rømme, fastsatte en slesvigske forordning af 1614 straf for at skjule eller hjælpe bortløbne undergivne fra adelige godser. Til slut bredte livegenskabet sig over Slien til 10 godser i Angel. Det var en voldsom forringelse i forhold til den gamle nordiske bondefrihed. Den bevarede marskbønderne på den slesvigske vestkyst, hvor der ikke var herregårde, og en del af bønderne $\mathrm{i}$ Nord- og Mellemslesvig, hvor de andre bønder var fæstere med deraf følgende plagsomt hoveri m.m. Nogle bønder i Sundeved førte en lang proces ved overretten for at få fastslået, at de var selvejere og ikke fæstebønder. - En lignende retssag førtes i øvrigt nord for Kongeåen af Kolding-egnens bønder mod lensmanden på Koldinghus. I Danmark var oldtidens trældom forsvundet før 1300 (tilbage har vi dog ordet »træls «). Så opstod ganske vist efter år 1400 på Sjælland, Lolland og Falster det såkaldte vornedskab. Det betød, at bønder, som havde givet sig under en herremands værn, blev ufrie i den forstand, at de var bundet til godset og kunne sælges med dette; men de kunne ikke som de livegne sæiges personligt som et stykke kvæg. Vornedskabet ophævedes ved lov 1702; men 1733 indfortes for hele kongeriget bl.a. af militære grunde det såkaldte stavnsbånd, der bandt alle mænd under 40 år til godset. Tilmed var de oftest fæstere med hoveri. Stavnsbåndet var dog ikke så hårdt som livegenskabet, og det afskaffedes 1788 som led i de danske 
landboreformer. Først i de følgende år ophævedes livegenskabet i det sydøstlige Sønderjylland gradvis under pres fra København; det afskaffedes helt ved en kongelig forordning af 1804 .

\section{Dele af Jyske Lov overlevede}

Af Jyske Lovs middelalderlige regler brugtes endnu en hel del inden for civilretten, selv om tyske jurister $\mathrm{i}$ hertugdømmet rynkede på næsen ad disse gamle ting og talte hånligt om de bønder, der som lægdommere var medlemmer af retten, men i reglen ganske uegnede, fordi de ikke kunne fatte advokaternes tysk-latinske foredrag. Blandt det, som holdt sig, var arvereglerne, herunder at en broderlod var det dobbelte af en søsterlod. Det sidste gjaldt også ved fordeling af kirkestole, som dengang var et vigtigt tegn på velstand. De ansås for fast ejendom og blev overdraget ved skøde (skrevet på "tysk " som "Schjöte"). Og skødning foregik stadig efter Jyske Lov ved lovbydning på 3 tingdage, inden ejendommen kunne sælges til fremmede. Jeg har også fundet en sag fra Helgoland 1726 om en gammel matrone, der lod sig "fledføre «; det var en slags privat forsørgelseskontrakt efter Jyske Lov. Den ærværdige lov ophævedes først i år 1900, da Tysklands borgerlige lovbog (BGB) trådte i kraft; men dens ældgamle regler om formuefællig mellem ægtefæller gjaldt fortsat for personer, der var gift før 1900, og blev derfor anvendt langt hen $i$ dette århundrede, når der døde en rigtig gammel sønderjysk enke eller enkemand. Ved en særlig bestemmelse i BGB bevaredes endda ganske enkelte regler i Jyske Lov, bl.a. bestemmelsen om kongens (almenhedens, nu statens) ret til den frie, ubevoksede strandbred. Den har fået indflydelse på vor naturfredningslov.

\section{Danske fejlgreb i Sønderjylland, retslige og andre}

I øvrigt blev det oprindeligt danske hertugdømme ganske grundigt fortysket i løbet af 1700-tallet, så det for en tysk overklasses øjne tog sig ud som en temmelig tysk provins ved siden af Holsten, blot noget forstyrret ved »dansk indblanding " $\mathrm{i}$ de nordlige områder, hvor landbefolkningen ligesom $\mathrm{i}$ Mellemslesvig stadig talte et foragtet "platdansk «. Man må her huske på, at holstenerne også så ned på det fattige Jylland med de store heder og det magre kvæg, som måtte drives sydpå for at få kød på kroppen i marsken. Sønderjyllands fortyskning har jo en lang forhistorie. Den omfatter ikke blot holstensk magtudfoldelse og tyske angreb, men desværre også skæbnesvangre danske fejl og til andre tider dansk svigten eller sløvhed, både i grænselandet og i København. Det gælder ikke mindst på det retlige eller 
juridiske område. Det er sundt og rigtigt at undgå formalismen; men det er meget farligt at lade andre udforme en aftale eller ordning uden at undersøge, hvad der kan ligge bag en tilsyneladende uskyldig formulering. Så kan det senere vise sig, at det, der ved overfladisk læsning så ud som noget ret formelt, har tilsløret hårde og ubehagelige kendsgerninger. Vi noget troskyldige nordboere bør være vågne, når vi forhandler vigtige ting med folk fra andre lande, hvor man er vant til at bruge juridiske kunstgreb for at prøve at opnå fordele, som man ikke kunne få ved en direkte og klar aftale. Det er alt for letsindigt at berolige sig selv med, at det går jo nok, eller at det jo er en aftale mellem gentlemen. Det oplevede jeg selv noget af i 1949, da Sydslesvigsk Forening forhandlede med landsregeringens embedsmand $\mathrm{i}$ Kiel inden afslutningen af Kiel-aftalen. - Ved at se på perioden 1658-1721 i Sønderjyllands historie må man i hvert fald spørge sig selv, hvorfor Danske Kancelli gang på gang trak det korteste strå i forhold til Tyske Kancelli. I Hauchs sang om mordet på Knud Lavard lyder slutningsstrofen: „O Danmark, på rænker du aldrig dig forstod. Det har du tit betalt med dit reneste blod." Hvis man her ændrer den første sætning til: „O Danmark, på statsret du ikke dig forstod “, passer strofen ganske godt på de 50 år, der endte med Frederik 4.'s arvehyldning på Gottorp for 260 år siden.

Afgørende for den stærke tyske prægning af Sønderjylland i de næste 100 år var den nye store fejl i Danmarks grænsepolitik, der skete ved, at Frederik 4., trods faderens indskærpelse af det slesvigske spørgsmåls livsvigtige betydning for det danske rige, efter 1713 forsømte at hele det sår, det danske folkelegeme havde fảet mod syd. Derved fik de dygtige holstenere adgang til at fortsætte deres målbevidste politik med at fjerne Sønderjylland mere og mere fra Danmark indtil katastrofen i 1864, da hele Sønderjylland blev revet fra Danmark ved brutal prøjsisk magt og Bismarcks drevne politiske spil.

Det er en ringe trøst, at min egen generation har begået endnu en stor fejl ved at nægte det ivrigt danske Flensborg adgang til selvbestemmelsesret efter 1945, da kongens gamle by efter sine oplevelser med Prøjsen og Tyskland fra Bismarck til Hitlers tid igen stemte stærkt dansk ved valg efter valg. Siden denne fornægtelse af vore egne landsmænd syd for grænsen har jeg noget svært ved at tage det alvorligt, når danske politikere gør sig til talsmænd for folkelig selvbestemmelse i fjerne lande.

Men der lever stadig et ganske stærkt dansk sindelag i Sydslesvig. Bag det kan man af og til skimte den gamle forskel mellem nordisk og syd- eller mellemeuropæisk retsopfattelse og menneskesyn. For 30 år siden besøgte jeg en gammel bonde i Hollingsted ved vestenden af Danevirke. Han var ivrigt dansk, selv om han ikke kunne tale ret meget dansk; allerede i 1919 var han trods tysk politiovervågning med $\mathrm{i}$ arbejdet for den såkaldte 3 . zone, og efter 
1945 var han igen meget aktiv. På hans hylde stod et smukt eksemplar af Christian 4.'s plattyske udgave af Jyske Lov. Han var ganske klar over, at han der ejede en skat. "Den og Danevirke beviser, at vi ikke er tyske, men jyder ", sagde han. 
